\title{
Political Micro-Targeting in Europe: A Panacea for the Citizens' Political Misinformation or the New Evil for Voting Rights
}

\author{
Kirill Ryabtsev* \\ https://doi.org/10.21827/GroJIL.8.1.69-89
}

\author{
Keywords \\ RIGHT TO VOTE; ONLINE POLITICAL MICRO-TARGETING; ELECTION LAW
}

\begin{abstract}
Personalised interaction between political parties and the electorate has existed since the emergence of modern elections. Nowadays, digital technology has moved the relationship between political candidates and voters to a more advanced level. Through collecting and analysing citizens' personal data via digital means, politicians have the capacity to foresee the electorate's political behaviour, its preferences, and the choices it is inclined to make. Such campaign strategy is known as 'political micro-targeting', and it has raised great interest in academia. One may consider it a panacea for political misinformation, given that political micro-targeting can increase the population's participation in politics. Nonetheless, it can be argued that this phenomenon poses a long-term threat to democracy. Accordingly, due to the high engagement with personal data that political micro-targeting entails, the question of its compatibility with citizens' voting rights arises. This thesis will explore the issue of online political micro-targeting and seek to conduct a comparative analysis between presidential election campaigns in three European states, namely France, Italy and the United Kingdom. Accordingly, current political micro-targeting practices in these legal systems, and how they can influence each other, will be illustrated. An important place will be devoted to the analysis of political micro-targeting's interference with the electorate's voting rights and its regulatory framework.
\end{abstract}

\section{Introduction}

Elections lie at the heart of the democratic regime and form the essence of its core values. ${ }^{1}$ They give the people an opportunity to express their general will and choose those who will govern them. Accordingly, it is through democratic elections that the government of any democratic State obtains its legitimacy. ${ }^{2}$ Through electing their representatives, citizens have the right to hold them accountable if they do not adhere to the promised agenda. ${ }^{3}$ The electoral procedure also encourages political parties to efficiently prepare their programmes and respond to the will of the electorate. As a result, it is imperative that any kind of vote-rigging during election campaigns is averted to preserve the effectiveness of the elections. ${ }^{4}$

* LLB with Honours in International and European Law, Rijksuniversiteit Groningen; LLM with Honours in Law and Technology in Europe, Universiteit Utrecht. The author would like to thank Professor Sofia Ranchordás for her comments and feedback. All errors are his own.

1 David A Schultz, Election Law and Democratic Theory (Taylor \& Francis Group 2014) 45.

2 Jean-Jacques Rousseau, The Social Contract; or, Principles of Political Rights (first published 1762, Jonathan Bennett 2017) 57.

3 Anthony Barker, 'Accountability and Responsibility of Government and Public Bodies' (2001) 72(1) The Political Quarterly 132, 134.

4 Michael R Alvarez, Thad E Hall and Susan D Hyde, Election Fraud: Detecting and Deterring Electoral Manipulation (Brookings Institution Press 2008) 149. 
Nonetheless, in recent years, electoral campaigns have been shaped and arguably endangered by technological advancements. ${ }^{5}$ Due to the expansion of social media and the development of new technologies (eg big data, data science), political parties can personalise their targeting approach towards the citizens of their country and better respond to their needs. Such progress in the field of elections brings various benefits to society due to the customised nature of political agendas. ${ }^{6}$ Indeed, the opportunity of getting closer to an ordinary citizen through conducting a psychological analysis of the population can result in a new type of government, which can be rightfully called 'the servant of the people'. ${ }^{7}$ Notwithstanding the apparent benefits technology has brought to elections, it has also contributed to an increase in the level of electoral fraud. ${ }^{8}$ By predicting citizens' political choices and further exploiting them, political parties are interfering with the very essence of elections. These activities are better known as online political microtargeting. Accordingly, by way of creating data-driven elections and simplifying voterigging by political candidates, they constitute an imminent threat to the values lying at heart of any democratic regime. ${ }^{9}$

The first trace of online political micro-targeting and its regulation can be found in the United States. The leading case on the matter is the 2016 scandal surrounding Cambridge Analytica and Facebook. Using the personal data of Facebook users across the world, Cambridge Analytica facilitated personalised, online political advertisements for US politicians and thus influenced the population's voting choices. It must be emphasised that the involvement of Cambridge Analytica in States' political matters was further discovered in Europe, particularly in the United Kingdom (hereinafter 'the UK'). Nowadays, online political micro-targeting has become a highly relevant topic in the world of politics. Indeed, in many States worldwide there are a considerable number of cases in which it interferes with electoral procedures. ${ }^{10}$ Accordingly, due to its manipulative nature, such campaign practices are a remarkably contentious phenomenon from the perspective of the right to vote. However, not enough consideration has yet been given to this facet of online political micro-targeting.

This thesis will therefore examine to what extent online political micro-targeting in Europe interferes with the electorate's voting rights. It will conduct a comparative analysis

5 Moritz Hoferer and others, 'The impact of technologies in political campaigns' (2019) 538 Physica A: Statistical Mechanics and its Application 1, 2.

6 Frederik J Borgesius and others, 'Online Political Microtargeting: Promises and Threats for Democracy' (2018) 14(1) Utrecht Law Review 82, 85.

7 Muel Kaptein, The Servant of the People: On the power of integrity in politics and government (News \& Politics 2014) 15.

8 Hoferer and others (n 5) 16.

9 Tom Dobber, Ronan Ó Fathaigh and Frederik J Zuiderveen Borgesius, 'The regulation of online political micro-targeting in Europe' (2019) 8(4) Internet Policy Review <policyreview.info/articles/analysis/regulation-online-political-micro-targeting-europe> accessed 22 April 20205.

10 The United States can be a clear illustration of this statement. It is apparent that online political microtargeting was 'born' in the United States. It was largely used by the political leaders during both presidential and parliamentarian elections in order to influence the electorate's political views. For example, see Kate Kenski, Bruce W Hardy and Kathleen Hall Jamieson, The Obama Victory: How Media, Money, and Message Shaped the 2008 Election (OUP 2010) 252. Micro-targeting activities were also observed in the politics of Australia and Mexico, ror example, see Our Data Our Selves, 'Mexico: How Data Influenced Mexico's 2018 Election' (Our Data Our Selves, 2 July 2018) <ourdataourselves.tacticaltech.org/posts/overview-mexico> accessed 22 April 2020; Democratic Audit UK, 'How Australian activists used Obama-style micro-targeting in the 2016 elections' (Democratic Audit, 4 October 2016) <democraticaudit.com/2016/10/04/how-australian-activists-used-obama-style-microtargeting-in-the-2016-elections/> accessed 22 April 2020. 


\section{Political Micro-Targeting in Europe: A Panacea for the Citizens' Political}

Misinformation or the New Evil for Voting Rights 71

of three European States, namely France, Italy and the UK, and seek to illustrate how online political micro-targeting is regulated in these legal systems. Moreover, it will contrast this campaign strategy with the citizens' right to vote and show which threats and promises online political micro-targeting brings to this right. Importantly, this thesis will advocate for regulating online political micro-targeting instead of completely prohibiting it. It finds that due to the vast array of benefits it can have on political systems, online political micro-targeting can substantively contribute to fighting political misinformation.

This thesis will be divided into three chapters. In the first chapter, the reader will be presented with a theoretical background to online political micro-targeting and related incidents in the three above-mentioned States. Particularly, the hacking attack on Emmanuel Macron during the French presidential elections of 2017 will be explained. Moreover, Matteo Salvini and Luigi Di Maio's activities on Facebook will be analysed as providing a way for both candidates to win their seats in the Italian parliament during the Italian parliamentary elections of 2018. Lastly, online political micro-targeting conducted by the British Conservative party during the UK general election of 2019 will be discussed. In the second chapter, this thesis will elaborate on the scope of the right to vote and how it is protected by international, European and national legal systems. Moreover, the algorithms behind the drafting of online political micro-targeting strategies will be explained. The third chapter will elaborate on the issue which lies at the heart of this research, namely the interference of online political micro-targeting with the right to vote. It will discuss particular examples of how these campaign practices are endangering the right to vote and the possible consequences for democracy. Nonetheless, this chapter will also attempt to shed light on the positive side of online political micro-targeting and criticise its complete banning. It will seek to present the reader with a possible regulatory framework on online political micro-targeting and define the main actors responsible for its development.

\section{Online Political Micro-Targeting: A Theoretical Background A. General Overview: Modern Politics Shaped by ICT}

Electoral procedure fundamentally contributes to a government's democratic legitimacy and its claim to govern. ${ }^{11}$ Consequently, from the emergence of elections, politicians have been seeking to reach the electorate through the various channels available to them. ${ }^{12}$ For instance, before the social media era, politicians mainly sold their agenda via radio, television and newspapers. Moreover, political pronouncements in front of citizens were often made in order to create bonds with a certain candidate and gain the population's loyalty. ${ }^{13}$ The crucial political role played by churches also should not be underestimated. ${ }^{14}$ It was very common for a political candidate to seek endorsement from the priests of the church of the region whose confidence he wanted to earn. ${ }^{15}$ Lastly, the appearance of a

11 Schultz (n 1) 46.

12 Diana Owen, 'The Past Decade and Future of Political Media: The Ascendance of Social Media' in Michelle Baddeley (ed), Towards a New Enlightenment? A Transcendent Decade (BBVA's OpenMind 2019) 348 .

13 Bruno Latour, 'What if we Talked Politics a Little?' (2003) 2 Contemporary Political Theory 143, 156.

14 IWC van Wyk, 'The political responsibility of the church: On the necessity and boundaries of the theory of the two kingdoms' (2005) 61(3) HTS Teologiese Studies/Theological Studies 647, 653.

15 For instance, such campaign practices were widespread in the United States and South Africa; See David E Campbell, 'Acts of Faith: Churches and Political Engagement' (2004) 26(2) Political Behavior 155, 170. 
candidate was of highest importance. ${ }^{16}$ Even today, the way they dress, their family affairs and other activities outside the political realm (e.g. charity and volunteering) play major roles in the politician's personal branding.

Accordingly, it is apparent that political leaders around the globe have always sought to interact closely with the population to win their trust and further ensure that the citizens' voice is heard. Therefore, it is not entirely correct to assume that political microtargeting is a completely new phenomenon, exclusively known to the modern community. ${ }^{17}$ However, Information and Communication Technology (hereinafter 'ICT') and, more importantly, social media, undoubtedly had a crucial impact on how politicians can interact with the electorate. These methods have more of a mass-targeting nature, rather than being a personal communication between an individual citizen and a political candidate. It is apparent, however, how Twitter and Facebook shaped political campaigning, which is now characterised by suspiciously highly-individualised political advertisements online. Here, the notion of online political micro-targeting came into existence. Through collecting personal data and other information about citizens, political candidates can conduct psychological analysis on the population and anticipate citizens' political views and choices. ${ }^{18}$ Politicians will further use this information to adapt their campaign programs to target a specific group of people within the electorate.

Therefore, it can be observed that modern politics experienced a shift from masstargeting to more concrete and individualised interactions. ${ }^{19}$ Two core factors can explain such an alteration. The first is an increase in the general standard of living of the population, as well as continued peace and security. ${ }^{20}$ Indeed, online political microtargeting is more widespread in more developed countries, such as the United States and European States, whereas politicians in less developed countries still use a more generalised approach to the electorate, bringing together citizens' core concerns and promising to solve problems such as hunger and poverty. Secondly, modern technologies have made the process of storing, processing and sharing citizens' personal data much faster and significantly cheaper for political parties. ${ }^{21}$ Hence, it further encourages them to invest in data science research and develop closer links between candidates and electors.

Nonetheless, the question still lying at the heart of political micro-targeting is to what extent it misguides citizens and whether more individualised relations between the government and the population are necessarily harmful. Apparently, while identifying targeted groups for self-advertising, politicians examine the people's needs, the problems they are experiencing and possible solutions. ${ }^{22}$ Modern technology, with all its potential, can drastically simplify this research and allow the government to create more effective

16 Margaret Scammell, 'Political Marketing: Lessons for Political Science' (1999) 47 Political Studies 718, 722.

17 Balázs Bodó, Natali Helberger and Claes H de Vreese, 'Political micro-targeting: a Manchurian candidate or just a dark horse?' (2017) 6(4) Internet Policy Review < policyreview.info/articles/analysis/politicalmicro-targeting-manchurian-candidate-or-just-dark-horse> accessed 22 April 20203.

18 Morgan E Currie, Britt S Paris and Joan M Donovan, 'What difference do data make? Data management and social change' (2019) 43(6) Online Information Review 971, 981.

19 Sanne Kruikemeier, Minem Sezgin and Sophie C Boerman, 'Political Microtargeting: Relationship Between Personalized Advertising on Facebook and Voters' Responses' (2016) 19(6) Cyberpsychology, Behavior, and Social Networking 367, 367.

20 Sophie Thomashausen, 'Addressing the 21st Century Threats to International Peace and Security: The Reform of the UN from a European Perspective' (2005) Fondation pour l'innovation politique 13.

21 Hao Zhang and Gang Chen, 'In-Memory Big Data Management and Processing: A Survey' (2015) 27(7) IEEE Transactions on Knowledge and Data Engineering 1920, 1924.

22 International IDEA, 'Digital Microtargeting Political Party Innovation Primer 1' (2018) International Institute for Democracy and Electoral Assistance 10. 


\section{Political Micro-Targeting in Europe: A Panacea for the Citizens' Political Misinformation or the New Evil for Voting Rights 73}

and practical policies. Moreover, online political micro-targeting represents an added value because it may give citizens the impression of a closer connection with a candidate which was often missing in the past elections. ${ }^{23}$ Indeed, earlier in the history of politics, citizens saw politicians as a distinct, elite class, often unreachable and somehow superior. However, modern social media bought political candidates closer to ordinary citizens and made their communication with the public more informal. Additionally, online political micro-targeting can result in a higher election turnout, ${ }^{24}$ thus in more voices being heard and the government representing the general will of the citizens in a fairer manner. Therefore, online political micro-targeting, if not misused, can strengthen the effectiveness of the citizens' political representation in State affairs.

However, it is conspicuous that online political micro-targeting also brought about numerous adverse consequences. ${ }^{25}$ For instance, due to the very nature of the online activities political micro-targeting entails, it is inevitably intrusive from a personal data protection perspective. The scandal revolving around Facebook and Cambridge Analytica perfectly illustrates this statement. ${ }^{26}$ The extraction of individual behavioural patterns among the electorate is achieved by obtaining the citizens' personal data without their prior consent. ${ }^{27}$ It brings up the phenomenon known as 'dataveillance': a concept encompassing the process of collecting all online activities of the population, storing them and, when necessary, allowing third parties to use them. ${ }^{28}$ Another equally crucial matter concerning online political micro-targeting is its undemocratic nature. Indeed, such aftereffects as mass manipulation by political leaders and data-driven elections create justifiable concerns from the perspective of a citizen's right to vote. ${ }^{29}$ This is the dimension of online political microtargeting that this thesis will further focus on. The following sections of this chapter will describe online political micro-targeting practices in France, Italy and the UK and give the reader valuable insights on the place of this phenomenon within their legal and political systems.

\section{B. The French Legal System: \#MacronLeaks}

It is important to note that French law forbids any kind of individual political microtargeting during election campaigns, including online campaigns. ${ }^{30}$ However, it is often a matter of interpretation when it comes to defining the individual nature of micro-targeting activities in the French legal system. The case of the 2017 French presidential elections sparked the interest of society after the hacking attack on Emmanuel Macron's email as an

23 Louis D Brandeis, 'Citizens and politicians' in World Development Report: Making Services Work for Poor People (The International Bank for Reconstruction and Development / The World Bank 2004) 78.

24 Borgesius and others (n 6) 85.

25 ibid 87.

26 Jim Isaak and Hanna J Mina, 'User Data Privacy: Facebook, Cambridge Analytica, and Privacy Protection' (2018) 9162(18) Computer 56, 57.

27 ibid.

28 Roger Clarke and Graham Greenleaf, 'Dataveillance Regulation: A Research Framework' (2017) UNSW Law Research Paper No.17-84, 4 <papers.ssrn.com/sol3/papers.cfm?abstract_id=3073492> accessed 22 April 2020; Anthony Nadler, 'Weaponizing the Digital Influence Machine: The Political Perils of Online Ad Tech' (2018) Data \& Society Research Institute 11.

29 Iva Nenadic, 'Data-driven Online Political Microtargeting: Hunting for Voters, Shooting Democracy?' (European University Institute: Robert Schuman Centre For Advanced Studies. Centre for Media Pluralism and Freedom, 8 March 2018) <cmpf.eui.eu/data-driven-online-political-microtargeting-hunting-for-votersshooting-democracy/> accessed 22 April 2020.

30 The French Electoral Code (as amended January 2020), arts L. 52-1, L. 163-1; Dobber, Fathaigh and Borgesius (n 9) 11. 
attempt to meddle with the campaign and destabilise his position in the eyes of French citizens and the global community. ${ }^{31}$ Various controversies had already appeared surrounding Macron's candidacy during runoff elections, such as monetary fraud and voterigging. ${ }^{32}$ The actual data leak happened at the last minute before the election silence and, unsurprisingly, spread widely via Internet. ${ }^{33}$ This leaked information included personal emails and other crucial documentation of Macron and his closest campaign teammembers. The WikiLeaks website made this data internationally available, ${ }^{34}$ thus creating a huge scandal around Macron's candidacy.

Although this attempt to hinder Macron's campaign failed, the hacking attack unveiled crucial information on Macron's campaign organisation. Firstly, it reaffirmed that the current French president used online political micro-targeting during his door-todoor campaign 'La Grande Marche'. ${ }^{35}$ Here, political views of French citizens were collected and further analysed by a digital platform designed by the company Liegey Muller Pons. ${ }^{36}$ In this way, Macron's team collected valuable information on the French electorate for the purpose of developing more personalised content for Macron's political advertisements. The French National Commission on Informatics and Liberty, the primary authority responsible for all issues related to data privacy, had earlier prohibited any type of individual micro-targeting during elections. ${ }^{37}$ Nonetheless, Macron's strategy was designed in a manner which allowed it to bypass this requirement. ${ }^{38}$ Accordingly, instead of individually profiling French citizens, he worked on a broader scale, analysing every French region and the political opinions shared by all of its inhabitants. However, it is arguable that such an approach still resembles online political micro-targeting in its nature. Indeed, regardless of this more generalised political profiling, Macron's team was collecting the population's personal data and further using it to manipulate, even indirectly, its political choices.

\section{The Italian Legal System: 2018 Parliamentary Elections and Facebook}

Contrary to the French case, the Italian legislation does not provide for any legal framework on online campaign regulations. ${ }^{39}$ Hence, the general elections of 2018 were fraught with online political advertisements. Two leaders of populist parties, Matteo Salvini and Luigi Di Maio, had actively used Facebook for their political campaign and, consequently, both won seats in the Italian parliament. ${ }^{40}$ Even though there was no official

31 Jean-Baptiste Jeangène Vilmer, 'The "Macron Leaks" Operation: A Post-Mortem' (2019) Atlantic Council IRSEM 4.

32 Megha Mohan, 'Macron Leaks: the anatomy of a hack' (BBC News, 9 May 2017) <bbc.com/news/blogstrending-39845105> accessed 22 April 2020.

33 Munish Sharma, 'Voter's Dilemma: Data Leaks and Electoral Interventions' (2017) IDSA 2.

34 WikiLeaks, 'Macron Campaign Emails' (WikiLeaks, 31 July 2017) <wikileaks.org/macron-emails/> accessed 22 April 2020.

35 International IDEA (n 22) 12.

36 Privacy International, 'Data analysis to improve electoral strategy (Liegey Muller Pons)' (Privacy International, 20 December 2017) <privacyinternational.org/examples/2842/data-analysis-improveelectoral-strategy-liegey-muller-pons> accessed 22 April 2020.

37 Colin J Bennett and David Lyon, 'Data-driven elections: implications and challenges for democratic societies' (2019) 8(4) Internet Policy Review <policyreview.info/data-driven-elections> accessed 22 April 20208.

38 International IDEA (n 22) 12.

39 Sofia Verza, 'Policy Brief: An overview of Italian online and offline political communication regulation' (2018) Global Freedom of Expression Columbia University 15.

40 Ammar Kalia, Caelainn Barr and Angela Giuffrida, 'Revealed: how Italy's populists used Facebook to win power' (The Guardian, 17 December 2018) <theguardian.com/world/2018/dec/17/revealed-howitaly-populists-used-facebook-win-election-matteo-salvini-luigi-di-maio> accessed 22 April 2020. 


\section{Political Micro-Targeting in Europe: A Panacea for the Citizens' Political Misinformation or the New Evil for Voting Rights 75}

proof that online political micro-targeting was employed by either Salvini's League Party or Di Maio's Five Star Party, the very nature of these campaign activities raised multiple concerns in relation thereto.

Firstly, it must be reiterated that both parties, particularly Salvini's League, actively used Facebook in order to get closer to the electorate. ${ }^{41}$ The messages they sought to deliver to voters were targeted towards groups who were more supportive of nationalist movementsand thus encouraged them to vote for Salvini. ${ }^{42}$ Moreover, it became apparent that the League was clearly dominating Facebook traffic and had the opportunity to build a more individualised relationship with the electorate. ${ }^{43}$ As was further observed, this approach led to a situation whereby Italian citizens tended to rely on information provided via social media more than any other source. ${ }^{44}$ It also allowed the League to bypass the mainstream media and exercise better control over the Italian electorate. ${ }^{45}$

Secondly, the structure and activities of the Five Star Party generated unease regarding online micro-targeting. ${ }^{46}$ This party is headquartered exclusively on the Internet and has its own advanced online political platform. ${ }^{47}$ All its members perform their political activities entirely online and, by expressing their political views and opinions via this platform, give the Five Star adequate information on the political choices they are inclined to make. ${ }^{48}$ Hence, by knowing exactly what the electorate wanted, Di Maio was able to deliver personalised messages and customised promises to the Italian people. ${ }^{49}$ Regardless of the tension surrounding online micro-targeting activities, both parties successfully won their seats in the Italian parliament. ${ }^{50}$

\section{The British Legal System: Brexit-Driven Elections of 2019}

The UK General Elections of 2019 can be rightfully called Brexit-driven. Debates on Brexit were spread over the Internet and propaganda flourished on social media from the first day the Brexit discussions started. In the British legal system, the 2003 Communications Act limits paid political advertisements solely to TV, radio and newspapers. ${ }^{51}$ However, it does not cover online advertisements. ${ }^{52}$ Hence, when the Brexit referendum took place in 2016, an immense online UK-leave advertisement campaign targeting specific citizens' groups

41 Kalia, Barr and Giuffrida (n 40).

42 Julia Carrie Wong, 'It might work too well': the dark art of political advertising online' (The Guardian, 19 March 2018) <theguardian.com/technology/2018/mar/19/facebook-political-ads-social-media-historyonline-democracy> accessed 22 April 2020.

43 Kalia, Barr and Giuffrida (n 40).

44 Sofia Verza, 'The regulation of political communication during electoral campaigns in Italy' (OBCT, 22 February 2019) <balcanicaucaso.org/eng/Projects2/ESVEI/News-Esvei/The-regulation-of-politicalcommunication-during-electoral-campaigns-in-Italy-193052> accessed 22 April 2020.

45 Kalia, Barr and Giuffrida (n 40).

46 Marta Musso and Marzia Maccaferri, 'At the origins of the political discourse of the 5-Star Movement (M5S): Internet, direct democracy and the "future of the past"' (2018) 2(1-2) Internet Histories 98, 99.

47 Liza Lanzone and Dwayne Woods, 'Riding the Populist Web: Contextualizing the Five Star Movement (M5S) in Italy' (2015) 3(2) Politics and Governance 54, 63.

48 Hannah Roberts, 'The dark side of Italy's Five Star movement' (The New European, 2 May 2018) $<$ theneweuropean.co.uk/top-stories/the-dark-side-of-five-star-italian-movement-1-5493911> accessed 22 April 2020.

49 ibid.

50 Kalia, Barr and Giuffrida (n 40).

51 The United Kingdom Communications Act 2003 (The UK Communication Act), art 333(3)

52 Dobber, Fathaigh and Borgesius (n 9) 12. 
was observed. ${ }^{53}$ Moreover, the Conservative party already employed online political micro-targeting in order to win the General Elections of $2015 .{ }^{54}$ Thus, a previously created comprehensive database of voters' preferences was re-used as a means to push the Brexit agenda. The Conservative party invested a great amount of resources into creating and spreading pro-Brexit propaganda on social media and presenting the idea of Brexit from an individualised perspective to every UK citizen. Arguably, many people were therefore misinformed about Brexit, and their vote influenced by misguided reasoning, resulting in a lack of understanding of the possible consequences of Brexit for the UK. ${ }^{55}$ It can therefore be argued that, from the very beginning, the whole Brexit debate was largely guided by online political micro-targeting. ${ }^{56}$

Additionally, the population's opinion on the UK leaving the EU was constantly shaped in this way even after the referendum took place in $2016 .{ }^{57}$ For the Conservatives, it was crucial to maintain the population's pro-Brexit attitude in order to win the upcoming parliamentary election. Unsurprisingly, when the 2019 UK general elections took place, they were again accompanied by millions of personalised advertisements and online Brexit propaganda. ${ }^{58}$ Resultantly, the Conservative party won the Brexit-led elections and Boris Johnson became UK's Prime Minister. As correctly stated by various scholars, online political micro-targeting once more played a crucial role in promoting a pro-Brexit attitude and closed this chapter on the future of the EU-UK relationship. ${ }^{59}$

\section{Diving Deeper: From Theory to Practice}

\section{A. Right to Vote: Definition, Scope and Limitations}

The main research focus of this paper is the interplay between online political microtargeting and the right to vote. This right, otherwise known as active suffrage, is a centrepiece of any democracy as it secures that the voices and opinions of all citizens will be heard. ${ }^{60}$ The nature of this right is complex and raises questions relating to the scope of the right to vote and any legally acceptable grounds for its restriction. Finding the answer to these questions and unpacking the nature of the right to vote is crucial in order to properly evaluate how it is affected by online political micro-targeting.

53 Mark Scott, 'Cambridge Analytica did work for Brexit groups, says ex-staffer' (Politico, 30 July 2019) <politico.eu/article/cambridge-analytica-leave-eu-ukip-brexit-facebook/> accessed 22 April 2020.

54 Borgesius and others (n 6) 84.

55 Max Hänska and Stefan Bauchowitz, 'Tweeting for Brexit: how social media influenced the referendum' in John Mair and others (eds), Brexit, Trump and the Media (Abramis Academic Publishing 2017) 29.

56 Mark Scott, 'Cambridge Analytica helped "cheat" Brexit vote and US election, claims whistleblower' (Politico, 27 March 2018) < politico.eu/article/cambridge-analytica-chris-wylie-brexit-trump-britain-dataprotection-privacy-facebook/> accessed 22 April 2020.

57 Ryan Browne, 'Britain's Brexit election has become plagued by fears of online manipulation' (CNBC, 11 December 2019) <cnbc.com/2019/12/11/uk-election-experts-fear-online-manipulation-in-politicalads.html $>$ accessed 22 April 2020.

58 Matthew Field and Mason Boycott-Owen, 'Microtargeting: How the Tories are deploying hundreds of Facebook ads as party swings into campaign mode' (The Telegraph, 31 July 2019) $<$ telegraph.co.uk/technology/2019/07/30/microtargeting-tories-deploying-hundreds-ads-facebookparty/> accessed 22 April 2020.

59 Linda Risso, 'Harvesting Your Soul? Cambridge Analytica and Brexit' in Christa Jansohn (ed), Brexit means Brexit? (Akademie der Wissenschaften und der Literatur 2018) 80; Natasha Lomas, 'Brexit ad blitz data firm paid by Vote Leave broke privacy laws, watchdogs find' (Tech Crunch, 27 November 2019) $<$ techcrunch.com/2019/11/27/brexit-ad-blitz-data-firm-paid-by-vote-leave-broke-privacy-lawswatchdogs-find/> accessed 22 April 2020.

60 Joshua A Douglas, 'Is the Right to Vote Really Fundamental' (2008) 18(1) Cornell Journal of Law and Public Policy 143, 149. 


\section{Political Micro-Targeting in Europe: A Panacea for the Citizens' Political}

Misinformation or the New Evil for Voting Rights 77

The two core legally-binding international documents which heavily influenced the French, Italian and British understandings of the right to vote are the European Convention on Human Rights (hereinafter 'ECHR') and the International Covenant on Civil and Political Rights (hereinafter 'ICCPR'). ${ }^{61}$ Firstly, Protocol No.1 to the ECHR emphasises that all people, regardless of their personal characteristics, should freely express their opinion regarding their choice of legislator. ${ }^{62}$ The ICCPR has a broader scope, covering not only the legislator, but also the executive and other administrative bodies. Additionally, both conventions require the abolition of arbitrary restrictions upon the enjoyment of the right to vote and that the secrecy of the voting procedure is ensured. ${ }^{63}$ Secondly, the right to vote is relevant to the analysis of another right recognised by the ECHR and the ICCPR: the right to free and fair elections. Indeed, it is imperative that the electorate casts their vote from their own free will, without any sort of manipulation or coercion. On that matter, the European Court of Human Rights (hereinafter 'ECtHR') established the presumption of the right to vote being included in the legal system of any democratic State. ${ }^{64}$ Additionally, the Human Rights Committee argues that the existence of free active suffrage is an imperative condition for elections to be considered valid. ${ }^{65}$

When it comes to limitations to the right to vote, the ECHR and ICCPR agree that the right is not absolute. Any restrictions, however, should be proportionate, objective and not arbitrary. ${ }^{66}$ Hence, limitations on such bases as sex, race, sexual orientation and physical capabilities are prohibited. The first acceptable basis for limitation to be discussed is nationality. The right to vote is usually applicable exclusively to the citizens of a particular State. The citizenship aspect is emphasised by the ICCPR, where the term 'citizen' is explicitly used in the Covenant and its General Comment 25. ${ }^{67}$ Nonetheless, this argument has been challenged after the introduction of the EU citizenship. Accordingly, the Treaty on the Functioning of the European Union and the EU Directive 94/80 allow foreign nationals of one Member State, legally residing on the territory of another Member State, to vote during its local and municipal elections. ${ }^{68}$ This broader application of the right to vote is in line with the ECHR's wording, wherein it uses the term 'people'. ${ }^{69}$ The second acceptable limitation of the right to vote is the voter's autonomy. It prescribes that only an individual who can autonomously make clear, rational and

61 International Covenant on Civil and Political Rights (adopted 16 December 1966, entered into force 23 March 1976) 999 UNTS 171 (ICCPR), art 25; Protocol No. 1 of the Convention for the Protection of Human Rights and Fundamental Freedoms (European Convention on Human Rights, as amended) [1952] (Protocol No. 1 ECHR), art 3; Avery Davis-Roberts and David J Carroll, 'Using International Law to Assess Elections' (2010) 17(3) Democratization 416, 420.

62 Protocol No. 1 ECHR (n 61) art 3.

63 European Court of Human Rights, 'Guide on Article 3 of Protocol No. 1 to the European Convention on Human Rights: Right to free elections' (Council of Europe 2019) 6; ICCPR, art 25.

64 Ludvig Beckman, 'The Right to Democracy and the Human Right to Vote: The Instrumental Argument Rejected' (2014) 13(4) Journal of Human Rights 381, 385; For example, see Scoppola v Italy (No. 3) App no 126/05 (ECHR, 22 May 2012) para 82.

65 Office of the High Commissioner for Human Rights 'General Comment No. 25: The right to participate in public affairs, voting rights and the right of equal access to public service' (12 July 1996) CCPR/C/21/Rev.1/Add.7, paras 10-11.

66 Beckman (n 64) 384.

67 ICCPR, art 25; Office of the High Commissioner for Human Rights (n 65) para 3.

68 Consolidated Version of the Treaty on the Functioning of the European Union (TFEU) [2016] OJ C202/1, art 22; Council Directive (EC) 94/80 laying down detailed arrangements for the exercise of the right to vote and to stand as a candidate in municipal elections by citizens of the Union residing in a Member State of which they are not nationals [1994] OJ L368/38 (Directive 94/80), art 3.

69 Protocol No. 1 ECHR (n 61), art 3. 
weighted decisions should be allowed to vote. Hence, votes from the people whose autonomy is not asserted cannot be considered valid and elections based on such votes are invalidated. ${ }^{70}$ Importantly, according to the ECHR and the ICCPR, the rationale behind the assessment of a person's autonomy should not be unreasonably discriminatory and should not result in the arbitrary exclusion of an entire group. ${ }^{71}$ Resultantly, the autonomy criterion, currently common to all European States, mainly covers a person's age and mental health. For instance, the French, Italian and British legal systems extend the right to vote only to citizens who have reached the age of majority and limit the voting rights of those whose mental sanity can reasonably be questioned. ${ }^{72}$ The third acceptable limitation is when a person loses their voting rights as a punishment for a committed crime. In such a case, the ICCPR and the ECHR prescribe that the duration of this deprivation should be proportionate to the offence. Importantly, both conventions and the ECtHR's case law state that mere imprisonment does not automatically deprive a person form his right to vote, unless this deprivation was a part of the punishment itself. ${ }^{73}$

Nowadays, the right to active suffrage in France, Italy and the UK implies that each citizen who has reached the age of majority should be able to freely vote for the candidate they find suitable to represent their interests. ${ }^{74}$ Additionally, these States believe that, for the right to vote to be successfully exercised by their citizens, the elections themselves must be transparent. ${ }^{75}$ This requirement, being one of the principles of good governance, ${ }^{76}$ allows citizens to freely choose their representatives and hold them accountable for non-fulfilment of their duties. ${ }^{77}$ It is also apparent that France, Italy and the UK recognise the importance of the right to vote to the electoral process. Indeed, they refrain from creating any unnecessary burdens on the exercise of this right and attempt to further protect its enjoyment. Accordingly, they control the amount of pressure exercised by politicians on the population's voting decisions by enacting statutes regulating political parties' campaign advertisements and ensuring the transparency of the electoral process. ${ }^{78}$ However, as

70 By analogy, see OSCE Office for Democratic Institutions and Human Rights, Guidelines for Reviewing a Legal Framework for Elections (2nd edn, OSCE ODIHR 2013) 18.

71 Beckman (n 64) 386.

72 The French Constitution adopted by referendum on 22 September 1958 (The French Constitution), art 3; The Italian Constitution adopted by the Constituent Assembly on 22 December 1947 (The Italian Constitution), art 48; The United Kingdom Representation of the People Act 1983 (The UK Representation Act), art 1.

73 European Court of Human Rights, 'Prisoners' right to vote' (European Court of Human Rights, 2019) 1; For example, see McHugh and Others $v$ United Kingdom App no 51987/08 (ECHR, 10 February 2015) para 11.

74 Adem Çaylak, 'Voting: A Citizen's Right or Duty? The Case of Compulsory Voting' (2017) 5(57) The Journal of Academic Social Science 418, 424.

75 European Commission, European Governance - A White Paper (White Paper, COM 428 final 22, 2001); Patrick Merloe, 'Human Rights - The Basis for Inclusiveness, Transparency, Accountability and Public Confidence in Elections' in John Harding Young (ed), International Principles for Democratic Elections (Sandler, Reiff \& Young 2008) 5.

76 Directorate General of Democracy and Political Affairs and Directorate of Democratic Institutions, "Project "Good Governance in the Information Society": Guidelines on transparency of e-enabled elections' (Council of Europe, 2011) 4.

77 Wilson Wong and Eric W Welch, 'Does E-Government Promote Accountability? A Comparative Analysis of Website Openness and Government Accountability' (2004) 17(2) Governance: An International Journal of Policy, Administration, and Institutions 275, 278.

78 World Wide Web Foundation and Transparency International, 'Open Data and the Fight Against Corruption in France' (Transparency International, 2017) 22; Transparency International UK, 'How Open is the UK Government: UK Open Governance Scorecard Results' (Transparency International, 2015) 5; Renato Ruffini, 'Transparency Policies in Italy: The Case of Venice Municipality' (2013) 10(6) Journal of US-China Public Administration 577, 579. 


\section{Political Micro-Targeting in Europe: A Panacea for the Citizens' Political}

Misinformation or the New Evil for Voting Rights 79

illustrated in the previous chapter, such laws are inadequate when it comes to successfully tackling online campaign activities ${ }^{79}$ thus creating a necessity for the scrutiny of online political micro-targeting.

\section{B. Behind the Scenes: Technologies Explained}

As illustrated in the previous chapter, political leaders in France, Italy and the UK collected citizens' personal data and analysed this in order to identify trends in their behaviour. Importantly, this process, known as data-mining, ${ }^{80}$ greatly assisted politicians in influencing the outcome of elections. Nonetheless, before discussing the compatibility of such activities with the right to vote, it is necessary to understand the algorithms behind online political micro-targeting. Hence, this section will seek to explain how French, Italian and British politicians draft their campaign strategies and the research methods they tend to use while preparing online political micro-targeting.

The logic behind the preliminary demographic categorisation of citizens often depends on the electoral system of the State.$^{81}$ Hence, it can happen that there is no need for one candidate to analyse the entire population's personal data and that it will suffice to focus on only one particular societal group. Undoubtedly, this significantly simplifies the design of online political micro-targeting, as it makes a clearer preliminary division of citizens and reduces the volume of data to be processed. For example, in the French 'Two Round' system and the British 'First Past the Post' system, ${ }^{82}$ the initial focus of Macron's and the UK Conservatives' data-mining was directed towards the citizens of a particular region (in France) or constituency (in the UK) ${ }^{83}$ On the contrary, the Italian 'Proportionate Representation' system would require Salvini and Di Maio to conduct data-mining of the entire population and individually target each voter. ${ }^{84}$ Moreover, there are other factors shaping this segmentation methodology that are worth mentioning. Here, three crucial concepts have to be discussed, namely data science, big data and trade of data. They appeared together with power upgrade of databases and, undoubtedly, are inherently connected to online political micro-targeting.

One must emphasise that any online political micro-targeting includes several preparation procedures. ${ }^{85}$ Firstly, data must be collected and analysed. At this stage, data

79 Alessandro Nai, Access to Justice and Electoral Integrity. A policy brief of the Electoral Integrity Initiative (Kofi Annan Foundation 2016) 10.

80 Hemlata Sahu, Shalini Shrma and Seema Gondhalakar, 'A Brief Overview on Data Mining Survey' (2013) 1(3) International Journal of Computer Technology and Electronics Engineering 114, 115.

81 International IDEA (n 22) 10.

82 In France, elections take place in two rounds. During the first round, citizens vote for a candidate of their preference. Importantly, candidates who get $12.5 \%$ of votes can proceed to the second round. The candidate who achieves the absolute majority of votes during the second round is declared winner. See Andre Blais, 'The French electoral and party system in comparative perspective' (2010) 8(1) French Politics 79, 80; In the UK, the system is a bit simpler. Seats in the UK Parliament are distributed according to the number of individual constituencies. In order for a candidate to get a seat, he has to basically win the most votes in his respective constituency. Hence, each constituency can be represented only by one political party. See David Klemperer, The Electoral System and British Politics (The Constitution Society 2019) 14.

83 International IDEA (n 22) 12.

84 Contrary to the French and British electoral systems, in Italy every political party can be represented in the Parliament. However, the number of seats each party can get is determined by the total number of votes this party receives. See Alessandro Chiaramonte and Roberto D'Alimonte, 'The new Italian electoral system and its effects on strategic coordination and disproportionality' (2018) 13(1) Italian Political Science 8, 10.

85 International IDEA (n 22) 11. 
science comes into play. As defined by the Cambridge Dictionary, this is the use of scientific methods to obtain useful information from computer data, especially large amounts of data' ${ }^{86}$ This multidisciplinary field appeared in the early 60 s and gradually evolved hand in hand with data-processing technologies. ${ }^{87}$ It includes such areas as data analytics, artificial intelligence, data mining, and machine learning. Modern data science structures and studies citizens' data, allowing political parties to improve the population's profiling, make more concrete predictions of voters' decisions and efficiently manipulate the outcome of elections. Importantly, when it comes to constructing behavioural models of the electorate and creating personalised political messages, politicians often resort to a linear regression statistical analysis. ${ }^{88}$ This data science method helps political candidates predict how the electorate will react to changes in the substance and presentation of their agendas, taking into account the personal characteristics of each voter. For instance, during the 2019 UK general elections, the Conservatives resorted to this technique in order to prepare and strategically spread individualised Brexit propaganda. ${ }^{89}$ They categorised citizens into groups based on their individual interests, financial and educational background, sexual orientation, age, race and sex to better understand the rationale behind their opinion on Brexit and successfully manipulate it.

Secondly, it is apparent that gathering and processing data from the entire population of a State requires an advanced technology, a procedure in which the big data phenomenon plays a crucial role. Big data cannot be stored and analysed via ordinary technological means and possesses five main characteristics: volume, variety, velocity, veracity, and value..$^{90}$ Accordingly, big data technology allows a large quantity of citizens' data to be collected, efficiently stored and rapidly processed by political leaders. An example of big data use can be the gathering by the League and Five Star parties of personal information about all Italian-national Facebook users eligible to vote during the 2018 Italian parliamentary elections. Furthermore, from this data it would be possible to extract the data concerning Italian citizens supporting Salvini and Di Maio's populist views. ${ }^{91}$ Importantly, it must be reiterated that there was no official evidence supporting the idea that these two candidates did resort to online political micro-targeting in their campaigns. Nonetheless, the considerable amount of their Facebook advertisements and the colossal reach they had during the 2018 Italian general elections demonstrate the recourse to big data technologies.

Additionally, online political micro-targeting often requires an exchange of personal data between political parties and different private companies (eg Facebook and

86 Cambridge Dictionary, 'Data Science' (Cambridge Dictionary, 2020) <dictionary.cambridge.org/dictionary/english/data-science> accessed 22 April 2020.

87 Gil Press, 'A Very Short History Of Data Science' (Forbes, 28 May 2013) $<$ forbes.com/sites/gilpress/2013/05/28/a-very-short-history-of-data-science/\#4b095a8655cf> accessed 22 April 2020.

88 David W Nickerson and Todd Rogers, 'Political Campaigns and Big Data' (2013) HKS Working Paper No. RWP13-045, 12 <papers.ssrn.com/sol3/papers.cfm?abstract_id=2354474> accessed 22 April 2020.

89 Eleonora Alabresea and others, 'Who voted for Brexit? Individual and regional data combined' (2019) 56 European Journal of Political Economy 132, 133.

90 It is necessary to further explain these characteristics. Firstly, the volume aspect of big data refers to the quantity of stored data. Secondly, the variety aspect of big data describes the nature and diversity of this data. Thirdly, big data's veracity shows the quality of gathered data and its value. Fourthly, the value aspect describes the extent of the usefulness of the data and its potential to assist the researchers in the performance of their task. Lastly, the velocity of big data illustrates the speed of the generation and processing of the data; see Youssra Riahi and Sara Riahi, 'Big Data and Big Data Analytics: Concepts, Types and Technologies' (2018) 5(9) International Journal of Research and Engineering 524, 525.

91 Kalia, Barr and Giuffrida (n 40). 
mobile service providers). ${ }^{92}$ Indeed, politicians must have a reliable source of voters' personal information and, unlike La Grande Marche, they are not always able to find it on their own. As clearly illustrated by the Cambridge Analytica scandal, citizen-profiling often involves other private entities who are already in possession of the required information. It must be emphasised that exchange of data was also drastically simplified by big data technologies, as the latter made the transfer of large volumes of data much faster and cheaper for the parties concerned. Resultantly, it can even take the form of outsourcing activities, for example when political leaders officially hire a private company entrusted with conducting research on the population's personal data and further developing online political micro-targeting strategies. For example, during the French presidential elections of 2017, the aforementioned company, Liegey Muller Pons, was accused of openly assisting Macron in profiling citizens. ${ }^{93}$

\section{Democracy Hacked and How to Deal with It}

\section{A. Data-Driven Elections vs Right to Vote: A New Challenge to Democracy?}

There is no doubt that the right to vote is affected by online political micro-targeting, regardless of the seemingly extensive legal framework protecting it. Indeed, the algorithms and manipulative techniques behind these campaign practices endanger various aspects of the right to vote and threaten citizens' enjoyment thereof. ${ }^{94}$ Consequently, the very essence of free elections is undermined, leading to the dismantlement of the democratic regime. This section will discuss the two primary ways in which online political micro-targeting is interfering with the right to vote and the major consequences of this intrusion.

As illustrated in the previous chapter, new technologies simplified the access of political parties to information about the electorate and allowed them to abuse this knowledge for their own benefit. Today, via predictive algorithms involved in online political micro-targeting, politicians can foresee how an individual will react to particular information in their agendas. Therefore, they can individualise their campaign promises and influence, and eventually manipulate, citizens' free will when it comes to making cognitive voting decisions. Consequently, the phenomenon of data-driven elections occurs and is characterised by two major consequences: ${ }^{95}$ firstly, peoples' engagement in a State's political affairs can be predicted, controlled and changed according to a party's interests. ${ }^{96}$ For instance, this was successfully done by Salvini and Di Maio via the online targeting of people with populist views and actively encouraging and pushing them to vote. Accordingly, the 2018 Italian general elections had a huge participation rate of citizens supporting the nationalistic views of the League and Five Star. ${ }^{97}$ Similarly, the UK Conservative Party successfully suppressed voter turnout for the Labour Party during the 2019 UK general elections, but meanwhile strongly encouraged pro-Brexit citizens to make

92 Kevin Köner, 'Digital politics: AI, big data and the future of democracy' (Deutsche Bank Research: EU Monitor Digital Economy and Structural Change, 2019) 8.

93 Varoon Bashyakarla, 'France: Data Violations in Recent Elections' (Tactical Tech, 2018) <ourdataourselves.tacticaltech.org/posts/overview-france> accessed 22 April 2020.

94 Alvarez, Hall and Hyde (n 4) 77.

95 Bennett and Lyon (n 37) 8.

96 Nickerson and Rogers (n 88) 3.

97 The Guardian, 'Italian elections 2018 - full results' (5 March 2018) <theguardian.com/world/nginteractive/2018/mar/05/italian-elections-2018-full-results-renzi-berlusconi> accessed 22 April 2020. 
their voices heard.$^{98}$ Hence, politicians promulgate political polarisation ${ }^{99}$ by blocking the activities of those who can jeopardise their party's success and by actively stimulating others supporting their agenda to vote. ${ }^{100}$ Similarly, political leaders can exclude an entire societal group from political participation. ${ }^{101}$ For instance, people who are politically inactive or those whose involvement will not have any substantive impact on the party's victory are often ignored for cost-efficiency reasons. ${ }^{102}$ Additionally, there may be issues of underrepresentation of some social groups through the suppression of political parties that cannot afford or are not willing to resort to online political micro-targeting during their campaign. This occurred in Italy, where the League dislodged many of its opponents who were not producing enough advertisements on Facebook. ${ }^{103}$ Lastly, as argued by the European Commission, online political micro-targeting lacks transparency when it comes to segmentation of the population. ${ }^{104}$

Secondly, online political micro-targeting frequently involves the spreading of fake news and disinformation. ${ }^{105}$ Thus, by manipulating people into blindly believing information on social media, politicians attempt to ensure that citizens will be biased and base their decisions on facts that turn out to be wrong, but beneficial for the party. This was clearly illustrated by Macron's email hacking. An unknown attacker revealed a lot of controversial information about the current French president in an attempt to undermine his reputation both in France and internationally. ${ }^{106}$ Therefore, based on what was displayed on social media, many French citizens were indirectly forced to change the party they supported, even though it could contradict their political beliefs. Misinformation can also occur as a direct consequence of how political candidates brand themselves and their programmes for different societal groups or regions. ${ }^{107}$ For instance, the Conservatives presented their Brexit agenda from one perspective in Beckenham and from a slightly different other in Aberconwy, but in the end both constituencies voted for the Conservative candidates. ${ }^{108}$ Moreover, in its Brexit agenda, the Conservatives intentionally focused the

98 Caroline Davies, 'Conservatives accused of suppressing voters' rights over leaked photo ID plans' (The Guardian, 13 October 2019) <theguardian.com/politics/2019/oct/13/conservatives-accused-of-electionrigging-leaked-id-plans-voter-fraud> accessed 22 April 2020.

99 Sounman Hong and Sun Hyoung Kim, 'Political polarization on twitter: Implications for the use of social media in digital governments' (2016) 33 Government Information Quarterly 777, 781; European Parliament, 'Polarisation and the use of technology in political campaigns' (Panel for the Future of Science and Technology, 2019) 22.

100 Borgesius and others (n 6) 87.

101 ibid 88.

102 Jesper Strömbäck, 'Political Marketing and Professionalized Campaigning: A Conceptual Analysis' (2007) 6(2-3) Journal of Political Marketing 49, 61.

103 Silvia S Borrelli, 'League wins landslide victory in Italian regional election' (Politico, 28 October 2019) <politico.eu/article/league-wins-landslide-victory-in-italian-regional-election/> accessed 22 April 2020.

104 Dobber, Fathaigh and Borgesius (n 9) 12.

${ }^{105}$ Kate Jones, 'Online Disinformation and Political Discourse Applying a Human Rights Framework' (Chatham House The Royal Institute of International Affairs, 2019) 7.

106 Vilmer (n 31) 13.

107 Borgesius and others (n 6) 89.

108 BBC, 'UK results: Conservatives win majority: Beckenham Parliamentary constituency' (BBC, 13 December 2019) <bbc.co.uk/news/politics/constituencies/E14000551> accessed 22 April 2020; BBC, 'UK results: Conservatives win majority: Aberconwy Parliamentary constituency' (BBC, 13 December 2019) <bbc.com/news/politics/constituencies/W07000058> accessed 22 April 2020; Eleanor Busby, 'Brexit "propaganda" appeared on school digital noticeboards, MP claims' (The Independent, 26 September 2019) <independent.co.uk/news/education/education-news/brexit-propaganda-borisjohnson-schools-stella-creasy-walhamstow-a9121941.html> accessed 22 April 2020. 


\section{Political Micro-Targeting in Europe: A Panacea for the Citizens' Political Misinformation or the New Evil for Voting Rights 83}

discussion on matters many people thought were endangered by the EU, ${ }^{109}$ such as national identity and UK sovereignty. However, it is apparent that the negative consequences following Brexit, such as the loss of EU citizenship, were intentionally underestimated. This example clearly demonstrates how online political micro-targeting identifies issues individual citizens are concerned about and filters them in a manner that allows politicians to display only information that is potentially beneficial to their political party. On the contrary, matters equally crucial to citizens, but which, under normal circumstances, would negatively influence the outcome of the elections, will be hidden or refashioned into trivial information.

Consequently, such usage of online political micro-targeting unravels the enjoyment of a citizen's right to vote. Firstly, due to its dissimulated and non-transparent character, online political micro-targeting causes information asymmetry between politicians and voters. ${ }^{110}$ Ordinary citizens are not aware of how online political microtargeting operates or of possible means to protect themselves from its influence. Not having the same level of access to such information additionally increases the magnitude of the knowledge gap between voters and political parties. Therefore, without being acquainted with when and how its personal data are used, the electorate becomes vulnerable to manipulation and cannot 'self-legislate' on the protection of its right to vote. ${ }^{111}$ Politicians, by contrast, can more easily ignore the interference with the right to vote in their campaign activities and avoid being held accountable for their undemocratic actions. ${ }^{12}$ This situation further results in non-discrimination and transparency requirements being violated, as politicians can secretly choose which societal groups they want to encourage to vote and whose voting capacity they will suppress. ${ }^{113}$ Voters, however, do not know under which logic they are being targeted. Thus, universal and equal active suffrage transforms into a right to vote indirectly granted by political leaders to citizens on a strategic and concealed basis. Lastly, such campaign practices are endangering citizens' autonomy and creating reasonable concerns regarding their rational decision-making capacities. ${ }^{114}$ Online political micro-targeting makes people's voting decisions disproportionately dependent on, and shaped by, the information displayed by politicians on social media. ${ }^{115}$ Resultantly, it is arguable that votes cast under the influence of online political micro-targeting cannot be considered valid. Moreover, elections won primarily by votes acquired through online political micro-targeting should also be invalidated. ${ }^{116}$

\section{B. To Forbid, or Not to Forbid, That is the Question}

109 European Committee of the Regions and Commission for Economic Policy, 'Assessing the impact of the UK's withdrawal from the EU on regions and cities in EU27' (European Union, 2018) 55.

${ }^{110}$ Mireille Hildebrandt, 'Profiling and the rule of law' (2008) 1 Identity in the Information Society 55, 62.

${ }^{111}$ Haye Hazenberg and others, 'Micro-Targeting and ICT media in the Dutch Parliamentary system. Technological changes in Dutch Democracy' (2018) TU Delft Design for Values 21.

112 ibid.

113 Casper R Sunstein, \#republic Divided Democracy in the Age of Social Media (Princeton University Press 2017) 133.

114 Jeff Chester and Kathryn C Montgomery, 'The role of digital marketing in political campaigns' (2017) 6(4) Internet Policy Review <policyreview.info/articles/analysis/role-digital-marketing-politicalcampaigns $>$ accessed 22 April 20208.

115 For the British example, see Damian Tambini and others, 'Media Policy Brief 19: The new political campaigning' (2017) LSE Media Policy Project 10.

${ }^{116}$ International IDEA, Electoral Justice: An Overview of the International IDEA Handbook (International Institute for Democracy and Electoral Assistance 2010) 31. 
The regulatory matters around online political micro-targeting from the perspective of the right to vote are highly complex. As specified in the previous chapters, neither Italy nor the UK have a concrete legal framework on online campaign activities and French law has a very limited scope regarding individual political targeting. The absence of case law on the link between online political micro-targeting and the right to vote makes this topic even more ambiguous. ${ }^{117}$ Resultantly, the perpetual debate regarding further control mechanisms is ongoing. On the one hand, there are those advocating for a complete ban of online political micro-targeting. On the other hand, others are searching for an efficacious legal framework that would allow the employment of these campaign practices for society's benefit. This section will criticise the former school of thought and attempt to discuss possible ways of regulating online political micro-targeting.

The current attitude of the British and Italian governments towards online political micro-targeting is largely based on the laissez-faire principle. ${ }^{118}$ A similar situation can arguably be identified when it comes to EU law or ECtHR case law, as none of these systems have specific rules dealing with online political micro-targeting. At the opposite end of the spectrum, France has entirely prohibited all kinds of individual political targeting. The latter approach was applauded by scholars and practitioners for its directness and arguable success. ${ }^{119}$ The rationale behind banning online political micro-targeting is straightforward. Some scholars argue that such undemocratic practices, greatly imperilling not only the right to vote but also other fundamental rights and values, should be entirely prohibited. ${ }^{120}$ Undoubtedly, such an approach has its advantages. For instance, it is more time efficient, as a blanket prohibition is usually easier and faster to arrange than a more complex regulatory system. Moreover, this proposal is more beneficial resource-wise as there is no need to hire researchers, policy makers and academics. Lastly, online political micro-targeting violates many other laws in addition to those related to elections and the right to vote, such as legislation on protection of privacy and personal data. ${ }^{121}$ Hence, it is not a complicated task to find an appropriate legal basis in national or EU law allowing the legislature to strike down these campaign practices. Consequently, at first glance, such approach towards online political micro-targeting can be a workable solution. ${ }^{122}$

Nonetheless, such an approach has clear drawbacks and is highly short-sighted. Firstly, it can be criticised from a procedural point of view, as it is unclear by which institution a ban of online political micro-targeting would be initiated. The legislature or the executive would be the initial idea; however, due to lack of interest in the matter this is highly unlikely to happen. Indeed, from the perspective of politicians who have won elections by employing online political micro-targeting, it would be foolish to enact legislation prohibiting it and thus diminishing their chances of getting re-elected. On the contrary, it is more foreseeable that, in order to prevent dissatisfaction among the electorate and to avoid scandals similar to that of Cambridge Analytica, ${ }^{123}$ legislative initiative towards the legalisation and regulation of such campaign activities is more probable.

\footnotetext{
117 Dobber, Fathaigh and Borgesius (n 9) 7.

118 ibid 12.

119 European Data Protection Supervisor, 'EDPS Opinion on Online Manipulation and Personal Data' (2018) Opinion 3/2018 18.

120 ibid 6.

121 Tom Dobber and others, 'Spiraling downward: The reciprocal relation between attitude toward political behavioral targeting and privacy concerns' (2019) 21(6) New Media \& Society 1212, 1220.

122 Borgesius and others (n 6) 95.

123 Julia Carrie Wong, 'The Cambridge Analytica scandal changed the world - but it didn't change Facebook' (The Guardian, 19 March 2019) <theguardian.com/technology/2019/mar/17/the-cambridgeanalytica-scandal-changed-the-world-but-it-didnt-change-facebook> accessed 22 April 2020.
} 


\section{Political Micro-Targeting in Europe: A Panacea for the Citizens' Political Misinformation or the New Evil for Voting Rights 85}

Secondly, the complete prohibition of online political micro-targeting should be criticised due to all the promises these campaign practices can bring to the right to vote. ${ }^{124}$ Undoubtedly, modern social media plays a crucial role in the life of almost every citizen. ${ }^{125}$ Previously, when the core channels of a political campaign were the mainstream media, the possibility for politicians to reach every citizen in a State was highly problematic. ${ }^{126}$ For instance, campaign advertisements were usually placed in specific politically-oriented journals, read exclusively by those interested in such topics. ${ }^{127}$ Additionally, many citizens tend to avoid broadcasting channels, deeming them full of political propaganda. ${ }^{128}$ On the contrary, online political micro-targeting allows political candidates to approach fringe groups (eg via social media), and is capable of sparking a higher interest in politics within the population. Additionally, statistics show that the French, Italian and British election turnout is decreasing every election. ${ }^{129}$ Some scholars argue that properly administrated online political micro-targeting can halt this decline by encouraging more people to become interested in the political life of their State. ${ }^{130}$

Thirdly, by providing citizens with information that is relevant to them, online political micro-targeting can increase the level of their consciousness regarding the analysis of political matters and render their voting decisions more weighted and substantial. Hence, by bringing a rational kernel to the electors' decision-making, it makes electoral procedures more efficient and effective. ${ }^{131}$ Lastly, radio, television and newspapers are more oriented towards a general body of citizens and usually highlight vaster problems. However, citizens would be more interested in seeing and feeling a personalised message from the government, targeting not only large-scale issues but also their individual concerns. Consequently, such campaign practices mobilise more citizens to rationally exercise their right to vote, and thus contribute to its promotion and strengthening. ${ }^{132}$

\section{The Regulatory Framework: Towards A New Era of Online Politics}

124 Judit Bayer, 'Double harm to voters: data-driven micro- targeting and democratic public discourse' (2020) 9(1) Internet Policy Review <policyreview.info/articles/analysis/double-harm-voters-data-drivenmicro-targeting-and-democratic-public-discourse $>$ accessed 22 April 20209.

125 The London School of Economics and Political Science, 'Social Media Platforms and Demographics' (2017) LSE Digital Communications 1.

126 Ilya Somin, Democracy and political ignorance: why smaller government is smarter (2nd edn, Stanford University Press 2016) 21.

${ }^{127}$ Henry E Brady, Richard Johnston and John Sides, 'The Study of Political Campaigns Capturing Campaign Effects' in Henry E Brady and Richard Johnston (eds), Capturing Campaign Effects (The University of Michigan Press 2006) 3.

128 Caroline Fisher, 'The trouble with "trust" in news media' (2016) 2(4) Communication Research and Practice 451, 458

129 BBC, 'French election: Turnout sharply down in Le Pen-Macron battle' (BBC, 7 May 2017) <bbc.com/news/world-europe-39833831> accessed 22 April 2020; Gianluca Passarelli and Dario Tuorto, 'Not with my vote: turnout and the economic crisis in Italy' (2014) 6(2) Contemporary Italian Politics 147, 151; Rod McInnes, 'General Election 2019: Turnout' (House of Commons Library, 7 January 2020) <commonslibrary.parliament.uk/insights/general-election-2019-turnout/> accessed 22 April 2020.

${ }^{130}$ Michael Bossetta, Anamaria Dutceac Segesten and Hans-Jörg Trenz, 'Engaging with European Politics Through Twitter and Facebook: Participation Beyond the National?' in Mauro Barisione and Asimina Michailidou (eds), Social Media and European Politics. Rethinking Power and Legitimacy in the Digital Era (Palgrave Studies in European Political Sociology 2017) 67; Borgesius and others (n 6) 85.

131 Borgesius and others (n 6) 85.

132 ibid 86. 
It is apparent from the previous chapter that the ECHR and the ICCPR established a general legal framework regarding the right to vote, its protection and limitations. However, due to the margin of appreciation and the degree of discretion given by both conventions to their State parties, ${ }^{133}$ France, Italy and the UK safeguard the right to vote differently. France and Italy state it in their respective constitutions and the UK spreads it among several acts of Parliament. ${ }^{134}$ On the one hand, the French and British legal provisions do not provide any further explanation of what the duties of the State on that matter are. They solely specify that the right to vote is indeed granted to citizens and what its accepted limitations are. Consequently, this often results in uncertainties regarding the extent of regulation of campaign activities and leaves room for discretion to the government and courts. Contrary to these cases, the Italian Constitution does not merely recognise the right to active suffrage, but also imposes several duties upon the government. Accordingly, it further obliges the Italian authorities to make extra efforts to secure and promote the enjoyment of the right to vote. ${ }^{135}$ Such an approach is decisive when it comes to scrutiny of online political micro-targeting as it provides an explicit legal basis for a stricter assessment of campaign activities from the perspective of the right to vote.

Unlike the right to vote itself, a comprehensive and far-reaching regulation of online political micro-targeting is not present in any of these three States. Indeed, as explained in the first chapter, even French law has loopholes when it comes to the prohibition thereof. ${ }^{136}$ Hence, there is an imperative for a new approach towards online political micro-targeting. Firstly, this regulatory scheme should involve stricter techniques to protect the universal and equal right to vote. Courts, for instance, should be encouraged to employ higher scrutiny towards violations of the right to vote, thus exercising a higher degree of control over all political campaign practices which may endanger it. Moreover, where possible, they should teleologically reinterpret the law and give old electoral concepts new meaning and scope. However, the courts' freedom of interpretation is limited and they may not always interpret the law too broadly. Thus, the legislator's input is of the highest importance. As with the French Electoral Code, ${ }^{137}$ Italian and British legislators should revamp current election laws, considering the influence of ICT, and provide courts and administrative authorities with necessary means of enforcement. Thus, alongside enlarging the protection of the right to vote, the State will facilitate control of online political microtargeting. Secondly, particular focus should be given to designing new rules to take advantage of the benefits of online political micro-targeting, but at the same time insulating it against the abuse of power. For instance, as illustrated by the 2019 European Parliament elections, ${ }^{138}$ a mandatory authorisation procedure on conducting online political microtargeting can be established across social media. However, instead of being conducted by the social media service itself, this procedure should be controlled by a special

${ }^{133}$ Kristin Henrard, 'A Critical Analysis of the Margin of Appreciation Doctrine of the ECtHR, with Special Attention to Rights of a Traditional Way of Life and a Healthy Environment: A Call for an Alternative Model of International Supervision' (2012) 4 The Yearbook of Polar Law 365, 367; Office of the United Nations High Commissioner for Human Rights, 'State Responsibilities to Regulate and Adjudicate Corporate Activities under the United Nations' core Human Rights Treaties: Individual report on the International Covenant on Civil and Political Rights Report No. III' (United Nations, 2007) 23.

134 The Italian Constitution, art 48; The French Constitution, art 3; The UK Representation Act, art 1(1).

135 The Italian Constitution, art 48; Alexander Kirshner, 'The International Status of the Right to Vote' (2003) Democracy Coalition Project 27.

136 Dobber, Fathaigh and Borgesius (n 9) 11.

137 The French Electoral Code, arts L. 52-1, L. 163-1; International IDEA (n 22) 14; ibid.

138 Dobber, Fathaigh and Borgesius (n 9) 12; Facebook for Business, 'Get Authorized to Run Ads About Social Issues, Elections or Politics' (Facebook for Business, 2020) <facebook.com/business/help/208949576550051?id=288762101909005> accessed 22 April 2020. 


\section{Political Micro-Targeting in Europe: A Panacea for the Citizens' Political}

Misinformation or the New Evil for Voting Rights 87

administrative authority. It may impose an obligation on any perpetrator of online political micro-targeting to specify the exact methodology their campaign tactics will employ. ${ }^{139}$ After their assessment, this administrative body will decide whether to allow this campaign strategy and, in case of an affirmative response, it will exercise careful supervision over it. Resultantly, resort to online political micro-targeting will be effectively overseen and its abuse by political parties will be strictly curtailed.

Nevertheless, a mere governmental response is insufficient. Political participation and the enhancement of the right to vote are directly connected to citizens' education. ${ }^{140}$ Hence, it is equally imperative to empower the population by providing citizens with necessary knowledge about the involvement of technology in politics. ${ }^{141} \mathrm{~A}$ particular emphasis should be given to making elections more transparent and enhancing people's access to literacy. ${ }^{142}$ Indeed, it is arguable that the success of online political micro-targeting in citizen manipulation occurred due to the fact that the vast majority of the population was not informed about the existence of this issue. The deficiency of a general citizen's ICT knowledge further made people highly vulnerable to external control though social media. ${ }^{143}$ Consequently, citizens should have open access to necessary information about online political micro-targeting, the algorithms behind it and how it impacts their voting rights. This information should be presented to them in a clear and understandable manner. ${ }^{144}$ Thus, it should include an explanation of the scope of the right to vote and its connection to other fundamental rights. Citizens must also know how the right to vote is shaped by ICT and the modern means of its protection and enforcement. ${ }^{145}$ Lastly, people should be aware of precautionary measures that can be taken independently to safeguard their right to vote from this modern hazard. Resultantly, such empowerment of the population will lead to two important outcomes. Firstly, a significant decrease of the information asymmetry between political candidates and the electorate will be achieved. ${ }^{146}$ Secondly, this change will further lead to a higher accountability of the government for possible manipulations, for neglecting their campaign promises and making their actions more people-oriented. ${ }^{147}$

\section{Conclusion}

139 Judit Bayer and others, 'Disinformation and propaganda - impact on the functioning of the rule of law in the EU and its Member States' (European Parliament, 2019) 122.

140 James M Vanderleeuw and Baodong Liu, 'Political Empowerment, Mobilization, and Black Voter RollOff' (2002) 37(3) Urban Affairs Review 380, 382.

141 Matthew Crain and Anthony Nadler, 'Political Manipulation and Internet Advertising Infrastructure' (2019) 9 Journal of Information Policy 370, 393.

142 Susan Morgan, 'Fake news, disinformation, manipulation and online tactics to undermine democracy' (2018) 3(1) Journal of Cyber Policy 39, 42.

143 Massimo Flore and others, 'Understanding Citizens' Vulnerabilities to Disinformation and Data-Driven Propaganda. Case Study: The 2018 Italian General Election' (2019) European Commission JRC Technical Reports 12.

144 For more information and examples of the complexity of vote-rigging detection, see Kathleen Hall Jamieson, 'Messages, Micro-targeting, and New Media Technologies' (2013) 11(3) The Forum 429, 433.

145 Lesley Farmer, 'Teaching Digital Citizenship' (2010) Selected Topics in Education and Educational Technology 387, 390.

146 Haye Hazenberg and others (n 111) 31; Alex Avramenko and Parveen Tamadon-Nejad, 'Internet innovations: exploring new horizons' (2014) 5(2) EJLT <ejlt.org/article/view/254/439> accessed 22 April 202010.

147 José María Maravall, 'Accountability and Manipulation' in Adam Przeworski, Susan C Stokes and Bernard Manin (eds), Democracy, Accountability, and Representation (CUP 1999) 161. 
Technological advancement has undoubtedly shaped the international community and the world of politics is not an exception. As illustrated by this thesis, ICT has remarkably influenced the way politics are conducted and brought communication between citizens and political candidates to a completely new level. Due to the development of dataprocessing systems, society has encountered the phenomenon of online political microtargeting. It has allowed politicians to closely interact with the electorate and to adapt their agendas to the citizens' needs and wants. Being a highly controversial topic, it has sparked discussion among legal practitioners and academics regarding the promise and threats these campaign practices have for democracy and its values.

This work has focused on the analysis of three European States where online political micro-targeting presumably took place during the latest elections, namely France, Italy and the UK. All three States have shown completely different types of online political micro-targeting due to the differences in their electoral and legal systems. However, they encountered one common consequence: the profiling of the electorate by political parties for the purposes of manipulation. Importantly, such an act of electoral fraud was facilitated from the perspectives of cost and time efficiency by other crucial factors, namely data science, big data and trade of data. Indeed, without the algorithms they comprise, the storage of such an immense amount of citizens' personal data and the statistical analysis necessary for the online political micro-targeting, strategy preparation would be rendered highly complicated. All of the above has resulted in the endangerment of the French, Italian and British populations' right to vote. Regardless of the existing legal framework on this right established by the ECHR and the ICCPR, France, Italy and the UK did little to secure it from this new threat. Moreover, the considerable magnitude of the ICT knowledge gap between political parties and citizens further exposed the electorate to manipulation by politicians. Accordingly, via internet and social media platforms, politicians can now control the type of information people will have access to and keep them unaware of being targeted.

It is possible to conclude that online political micro-targeting is indeed an issue that can negatively impact the right to vote, and thus the guarantee of free and fair elections. It has already entered the world of modern politics, and legal systems must adapt to it, thus reinterpreting legal provisions in light of developments in ICT. Nonetheless, it is incorrect to blindly stigmatise it as a phenomenon that is purely destructive to democratic regimes. Indeed, technologies are already able to drastically improve many aspects of life and contribute to the well-being of States and peoples around the globe. The crucial question which lies at heart of any innovation brought to the world is how society, and particularly people with power, will employ it.

This thesis has shown that online political micro-targeting is not undemocratic per se. Its deteriorating impact on the right to vote was caused not by the nature of the algorithms behind it, but due to the ways politicians around the world used it and the incapability of legal systems to hold them accountable in a timely manner. What is, in contrast, crucial to keep in mind is that online political micro-targeting may bring benefits to the community. Elections, just as any other process embodied in States' systems, should be open to change brought about by new technologies. It is irrational to rely on the option of simply forbidding online political micro-targeting. In contrast, it can only be seen as an attempt to delay the inevitable; electoral procedures being reshaped and adjusted to a new technological era. The history of elections and of the right to vote has already encountered similar developments, such as the establishment of the universal and equal suffrage principle. Thus, it is arguable that online political micro-targeting is just another novelty in this sector and is inherently connected to technologies that are becoming a part of the everyday life of every individual. 
Resultantly, a newly designed legal framework on online political micro-targeting is required, based upon the empowerment of citizens and strict regulation of political parties' activities online. Diminishing the knowledge gap between citizens and political parties, together with strict and far-reaching legal protection of the right to vote, will thus result in online political micro-targeting being contained within reasonable limits. Moreover, it will allow countries to efficiently take advantage of all the benefits which these campaign practices can bring to electoral procedures. Indeed, consequences such as an increase in voter turnout, the establishment of closer ties between politicians and citizens and the effective adaptation of political agendas based on the needs of the population, are capable of enhancing democracy and its values. Consequently, via employing online political micro-targeting for noble purposes, it will be possible to convert it from an evil to the right to vote into a panacea for political misinformation. 